\title{
Influence of size and plant growth regulators on corm and cormel production of gladiolus (Gladiolus grandiflorus L.)
}

\author{
MHA Rashid \\ Department of Horticulture, Bangladesh Agricultural University, Mymensingh 2202, Bangladesh
}

\begin{abstract}
Gladiolus is an excellent cut flower grown throughout the world for its spikes with florets of massive form, brilliant colours, attractive shapes, varying size and long shelf life. However, major constraint for gladiolus cultivation is the corm dormancy. Plant growth regulators (PGRs) play an important role in breaking dormancy and promote more number of quality corm and cormel productions in gladiolus. Therefore, an experiment was conducted to study the influence of corm size and plant growth regulators on corm and cormel production of gladiolus during the period from October 2017 to April 2018 at the Landscaping section of the Department of Horticulture, Bangladesh Agricultural University, Mymensingh. The two-factor experiment included two corm sizes viz., 3-4 cm and 4.1-5 cm, and two PGRs viz., GA $@$ @ 250, 500 and 750 ppm; and NAA @ 100, 200 and 300 ppm along with tap water as control. The experiment was laid out in a randomised complete block design (RCBD) with three replications. The results revealed that the corm size and PGRs at different concentrations significantly influenced the corm and cormel producing attributes of gladiolus. Maximum number of corms and cormels per plant, maximum weight of single corm, maximum weight of corms and cormels per plant, biggest size of single corm, highest yield of corms and cormels per hectare were recorded from 4.1-5 cm sized corms and $\mathrm{GA}_{3} @ 500$ ppm, compared to rest of the treatments. It was observed that combined treatments had significant influence on all the parameters studied. The treatment combination of 4.1-5 cm sized corms and $\mathrm{GA}_{3} @ 500$ ppm was found to be best in terms of corm and cormel production of gladiolus.
\end{abstract}

Key words: Gladiolus, corm, cormel, $\mathrm{GA}_{3}$, NAA

Progressive Agriculturists. All rights reserved

*Corresponding Author: harun_hort@bau.edu.bd

\section{Introduction}

Gladiolus is one of the most important cut flowers cultivated worldwide for its elegant attractive spikes of variations of colours and long vase life (Sinha and Roy, 2002). Gladiolus is monocotyledonous flowering bulbous plant, which have become integral part of commercial floriculture. Gladiolus (Gladiolus grandiflorus L.) belonging to the family Iridaceae also called the queen of bulbous flowers, has everincreasing demand in the flower markets (Roy et al. 2017). The flowers open from bottom to upwards. The flowers may be frilly, ruffled or plain, solid coloured or multi-coloured and they come in every shade and colour combination imaginable. The major producing countries are the United States (Florida and California), Holland, Italy, France, Poland, Bulgaria, Brazil, India, Australia and Israel (Memon et al. 2016). Gladiolus has a short life cycle of 110 to 120 days, require temperature regime between 10 and $25^{\circ} \mathrm{C}$. This crop possesses a great export potential to European countries especially during winter. Gladiolus is a native 


\section{Corm and cormel production of gladiolus}

of South Africa.

Commercial production of gladiolus is greatly influenced by the planting materials viz. corm, is the important factor which governs the growth and development of gladiolus (Sudhakar and Kumar, 2012). Smaller sizes of the corms are poor yielder, and larger sized corms add in cost of cultivation (Singh, 1992). Hence, it is essential to find out optimum size of corms for obtaining the best quality gladiolus production. Plant growth regulators control the physiological functions inside the corms. However, one of the major constraints for gladiolus cultivation is the corm dormancy (Baskaran et al. 2009). Plant growth regulators such as Gibberellins and Naphthalene acetic acid (NAA) play an important role in breaking dormancy, manipulating growth, flowering and promote more number of corm productions in gladiolus (Bhattacharjee 1983; Mahesh and Misra 1993; Baskaran and Misra 2007; Suresh Kumar et al. 2008). Plant growth regulators are the organic chemical compounds, which modify or regulate physiological processes in an appreciable measure in plants when used in small concentrations. They are readily absorbed and move rapidly through tissues when applied to different parts of the plant. It has generally been accepted that many plant processes including senescence, are controlled through a balance between plant hormones interacting with each other and with other internal factors (Mayak and Halevy, 1980). In Bangladesh, gladiolus is cultivated all over the country on smallholdings due to ever increasing demand of this elegant cut flower in various social and religious ceremonies (Mitra, 1992). In spite of its importance, very little information is available to the farmers on the effect of plant growth regulators on corm and cormel production of gladiolus. Hence, an experiment was conducted to study the influence of corm size and plant growth regulators on corm and cormel production of gladiolus.

\section{Materials and Methods}

The experiment was carried out at the Landscaping section of the Department of Horticulture, Bangladesh Agricultural University, Mymensingh during the period from October 2017 to April 2018. The experimental site was medium high land belonging to the Old Brahmaputra Floodplain under the Agro-Ecological Zone 9 having non-calcareous dark gray floodplain soil (UNDP and FAO, 1988). The soil was silty loam in texture and neutral $(\mathrm{pH}$ 7.0) in reaction which is suitable for gladiolus production. The experiment consisted of two factors viz. corm size (3-4 and 4.1-5 $\mathrm{cm})$ and PGRs $\left(\mathrm{GA}_{3} @ 250,500\right.$ and 750 ppm, and NAA@100, 200 and 300 ppm, along with control). The healthy corms of gladiolus of above 3-4 and 4.1-5 $\mathrm{cm}$ diameter were purchased from a private nursery of Jessore and rested for 6 months. The experimental area was cleaned first and tilled three to four times thoroughly followed by clod breaking, levelling, and layout was prepared manually. The rested corms were placed at room temperature for 15 days before plantation. Corms were soaked at different doses of plant growth regulator solutions and tap water for control for 12 hours and shade dried. The shade-dried treated corms were then planted at a spacing of $30 \times 30$ $\mathrm{cm}$ and depth of $5-6 \mathrm{~cm}$ in raised beds of $1 \mathrm{~m} \times 1 \mathrm{~m}$ dimensions in the month of October, following randomised complete block design with three replications. Fertilizers were applied at two split installments such as $1^{\text {st }}$ at the time of land preparation and $2^{\text {nd }}$ at the time of spike emergence. The land was applied with well-decomposed cowdung@10 kg/m $\mathrm{m}^{2}$ at the time of final land preparation. Nitrogen $(\mathrm{N})$ in the form of Urea, $P$ in the form of Triple Super Phosphate (TSP) and $\mathrm{K}$ in the form of Muriate of Potash (MoP) were applied at uniform dose to all plots and incorporated well with the soil during application. Gladiolus was grown with all recommended cultivation practices throughout the experiment. The observations were made on various corm and cormel producing characters viz. number of corms and cormels per plant, 
weight of single corm (g), weight of corms and cormels per plant $(\mathrm{g})$, corm size $(\mathrm{cm})$, yield of corms and cormels (t/ha). The collected data on various parameters were analysed statistically using MSTAT computer programme. The means for all the treatments were calculated and analysis of variance was performed by F-test. The mean difference between a pair of treatments was evaluated by LSD at $5 \%$ level of significance.

\section{Results and Discussion}

Effects of corm size: Experimental results revealed that corm sizes had significant effects on number of corms and cormels per plant, weight of single corm, weight of corms and cormels per plant, corm size, and yield of corms and cormels per hectare (Table 1, Figure $1 \& 2$ ).

Table 1. Individual effects of corm size and PGRs on corm and cormel production of gladiolus

\begin{tabular}{|c|c|c|c|c|c|c|}
\hline Treatments & $\begin{array}{c}\text { No. of } \\
\text { corms/ plant }\end{array}$ & $\begin{array}{c}\text { No. of } \\
\text { cormels/ } \\
\text { plant }\end{array}$ & $\begin{array}{l}\text { Weight of } \\
\text { single corm } \\
\text { (g) }\end{array}$ & $\begin{array}{c}\text { Weight of } \\
\text { corms/ plant } \\
\text { (g) }\end{array}$ & $\begin{array}{l}\text { Weight of } \\
\text { cormels/ } \\
\text { plant (g) }\end{array}$ & $\begin{array}{l}\text { Corm } \\
\text { size } \\
(\mathrm{cm})\end{array}$ \\
\hline \multicolumn{7}{|l|}{ Factor A: Corm size } \\
\hline$C_{1}: 3-4 \mathrm{~cm}$ & 2.06 & 12.61 & 47.74 & 98.30 & 4.36 & 5.05 \\
\hline $\mathrm{C}_{2}: 4.1-5 \mathrm{~cm}$ & 2.30 & 13.29 & 49.80 & 103.03 & 4.56 & 5.46 \\
\hline $\operatorname{LSD}_{(0.05)}$ & 0.03 & 0.15 & 0.26 & 0.41 & 0.05 & 0.05 \\
\hline Level of significance & $*$ & * & $*$ & $*$ & $*$ & $*$ \\
\hline \multicolumn{7}{|c|}{ Factor B: Plant growth regulators } \\
\hline $\mathrm{T}_{0}$ : Control & 1.37 & 8.72 & 31.15 & 38.70 & 2.65 & 3.92 \\
\hline $\mathrm{T}_{1}: \mathrm{GA}_{3} @ 250 \mathrm{ppm}$ & 1.85 & 13.78 & 53.25 & 95.87 & 4.27 & 5.52 \\
\hline $\mathrm{T}_{2}: \mathrm{GA}_{3} @ 500$ ppm & 2.62 & 16.50 & 59.68 & 148.20 & 5.35 & 6.37 \\
\hline $\mathrm{T}_{3}: \mathrm{GA}_{3} @ 750$ ppm & 2.33 & 12.93 & 57.60 & 114.08 & 4.23 & 6.05 \\
\hline $\mathrm{T}_{4}: \mathrm{NAA} @ 100$ ppm & 2.05 & 12.22 & 47.55 & 91.10 & 4.54 & 5.17 \\
\hline T5:NAA@200 ppm & 2.45 & 12.83 & 47.58 & 111.32 & 5.00 & 4.87 \\
\hline T6:NAA@300 ppm & 2.60 & 13.68 & 44.58 & 105.37 & 5.17 & 4.90 \\
\hline $\operatorname{LSD}_{(0.05)}$ & 0.07 & 0.27 & 0.48 & 0.77 & 0.09 & 0.10 \\
\hline Level of significance & $*$ & * & * & * & * & $*$ \\
\hline
\end{tabular}

$\mathrm{C}_{1}=3-4 \mathrm{~cm}, \mathrm{C}_{2}=4.1-5 \mathrm{~cm}, \mathrm{~T}_{0}=$ Control, $\mathrm{T}_{1}=\mathrm{GA}_{3} @ 250 \mathrm{ppm}, \mathrm{T}_{2}=\mathrm{GA}_{3} @ 500 \mathrm{ppm}, \mathrm{T}_{3}=\mathrm{GA}_{3} @ 750$ ppm, $\mathrm{T}_{4}=$ NAA@100 ppm, T $=$ NAA@200 ppm, T6=NAA@300 ppm

The higher number of corms per plant (2.30) was recorded in 4.1-5 $\mathrm{cm}$ sized corm $\left(\mathrm{C}_{2}\right)$, whereas the lower number of corms per plant (2.06) was recorded for 3-4 cm sized corm $\left(C_{1}\right)$. This is might be due to the enhancement of larger sized corm on the growth and development of gladiolus, which ultimately increased, the higher number of corms per plant. The result is in agreement with the findings of Mollah et al. (1995) and Bhat et al. (2009). Higher number of cormels per plant (13.29) was recorded in $4.1-5 \mathrm{~cm}$ sized corms $\left(\mathrm{C}_{2}\right)$, whereas the lower number of cormels per plant (12.61) was recorded for 3-4 cm sized corm $\left(C_{1}\right)$. According to 


\section{Corm and cormel production of gladiolus}

Hong et al. (1989), the number of cormels and flowering ability increased with increasing corm size up to 4 to $5 \mathrm{~cm}$ diameter, but there was no further increase for corms $>5 \mathrm{~cm}$ diameter. Higher weight of single corm (49.80 g) was recorded in $4.1-5 \mathrm{~cm}$ sized corms $\left(\mathrm{C}_{2}\right)$, while lower weight of single corm $(47.74$ g) was found from $3-4 \mathrm{~cm}$ sized corms $\left(C_{1}\right)$.

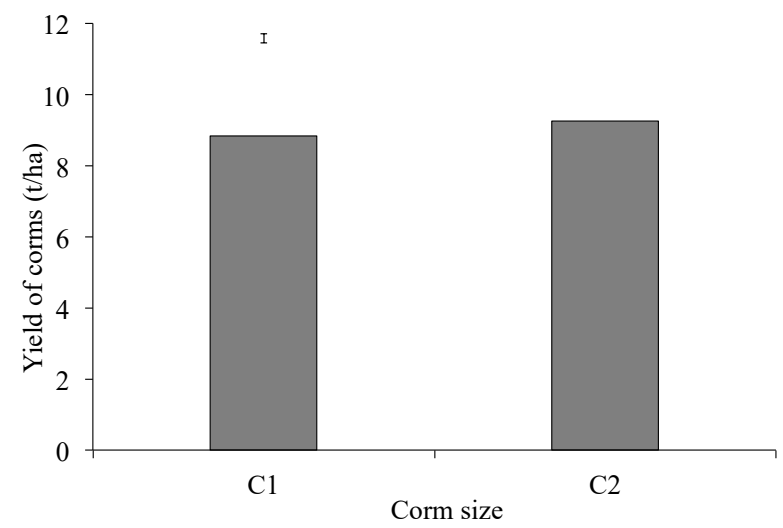

Figure 1. Effect of corm size on yield of corms. The vertical bar represents LSD 5\% level of probability.

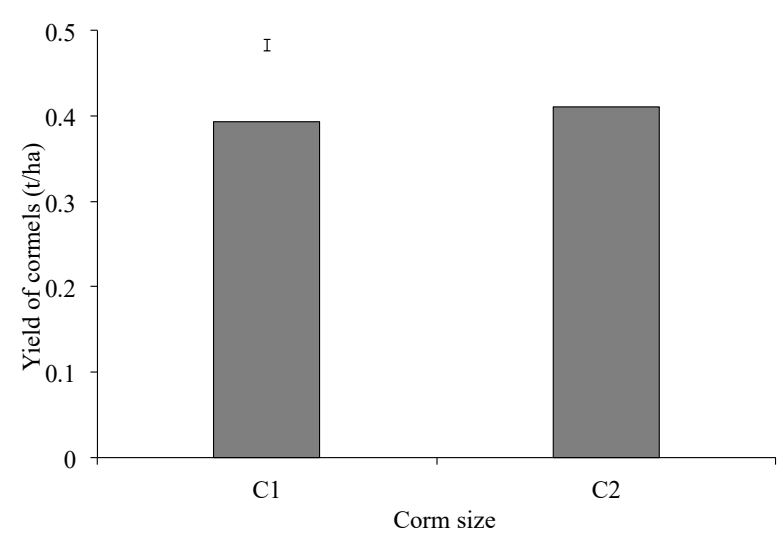

Figure 2. Effect of corm size on yield of cormels. The vertical bar represents LSD 5\% level of probability.

Higher weight of corms (103.03 g) and cormels (4.56 g) per plant was recorded in $4.1-5 \mathrm{~cm}$ sized corms $\left(\mathrm{C}_{2}\right)$, while, lower weight of corms (98.30 g) and cormels (4.36 g) was found from $3-4 \mathrm{~cm}$ sized corms $\left(\mathrm{C}_{1}\right)$, respectively. Weight of corms and cormel increased might be due to the increase in corm size. These results are supported by the findings of Mukhopadhyay and Yadav (1984) who also reported more flowers, corm and cormel production from larger corms of 4.6 to 5.0 $\mathrm{cm}$ diameter. Bigger size of the corms $(5.46 \mathrm{~cm})$ was recorded in $4.1-5 \mathrm{~cm}$ sized corms $\left(\mathrm{C}_{2}\right)$, whereas the smaller size of the corms $(5.05 \mathrm{~cm})$ was found from $3-4$ $\mathrm{cm}$ sized corms $\left(\mathrm{C}_{1}\right)$. The results of the present study is similar to the previous findings Singh (1996), Syamal et al. (1987) and Kalasareddi et al. (1998) who reported that large corms were superior in terms of number of shoots per corm, plant height, spike length, number of spikes, number of florets per spike and the diameter of corms produced. Higher corm (9.27 t/ha) and cormel yield $(0.410 \mathrm{t} / \mathrm{ha})$ were obtained from the $4.1-5 \mathrm{~cm}$ sized corms, while the lower corm (8.84 t/ha) and cormel yield (0.393 t/ha) were obtained from the 3-4 $\mathrm{cm}$ sized corms, respectively (Figure $1 \& 2$ ). These might be due to the accumulation of greater food materials in the larger size corm than the smaleer ones. McKay et al. (1981) reported that larger corm sizes exhibited greater yield of new corm and cormels as compared with smaller size corms.

Effects of plant growth regulators: The results of the present experiment showed that corm size had significant influence on number of corms and cormels per plant, weight of single corm, weight of corms and cormels per plant, corm size, and yield of corms and cormels per hectare of gladiolus (Table 1, Figure $3 \&$ $4)$. The greater number of corms (2.62) and cormels (16.50) per plant was produced by pre soaking treatment of $\mathrm{GA}_{3} @ 500$ ppm $\left(\mathrm{T}_{2}\right)$, while the smaller number of corms (1.37) and cormels (8.72) per plant was recorded from control $\left(\mathrm{T}_{0}\right)$. El- Meligy (1982), Dua et al. (1984) and Mahesh (1992) reported that increased number of corms and cormels in gladiolus by $\mathrm{GA}_{3}$ treatment. The maximum weight of single corm (59.68 g) was recorded by $\mathrm{GA}_{3} @ 500$ ppm $\left(\mathrm{T}_{2}\right)$ closely followed by $\mathrm{GA}_{3} @ 750$ ppm $\left(\mathrm{T}_{3}\right)$, while the minimum weight of single corm $(31.15 \mathrm{~g})$ was found in control $\left(\mathrm{T}_{0}\right)$, respectively. Similarly, the maximum 
weight of corms (148.20 g) and cormels (5.35 g) per plant was recorded the pre soaking treatment of $\mathrm{GA}_{3} @$ $500 \mathrm{ppm}\left(\mathrm{T}_{2}\right)$, while the minimum weight of corms $(38.70 \mathrm{~g})$ and cormels $(2.65 \mathrm{~g})$ per plant was found from control $\left(\mathrm{T}_{0}\right)$, respectively. This increase in weight of corms and cormels by $\mathrm{GA}_{3}$ might be due to their involvement in cell division, cell expansion and increased volume of intercellular spaces in the mesocarpic cells. These results are in agreement with the earlier findings by Khan et al. (2011) in gladiolus.

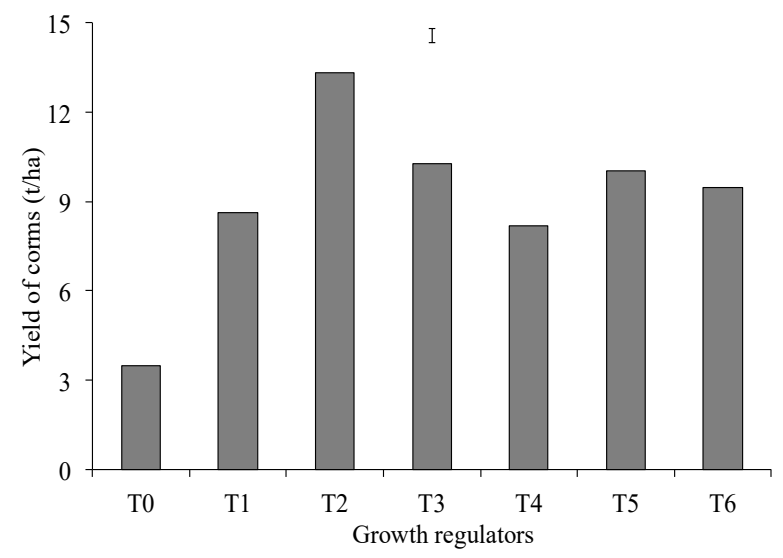

Figure 3. Effect of PGRs on yield of corms. The vertical bar represents LSD 5\% level of probability.

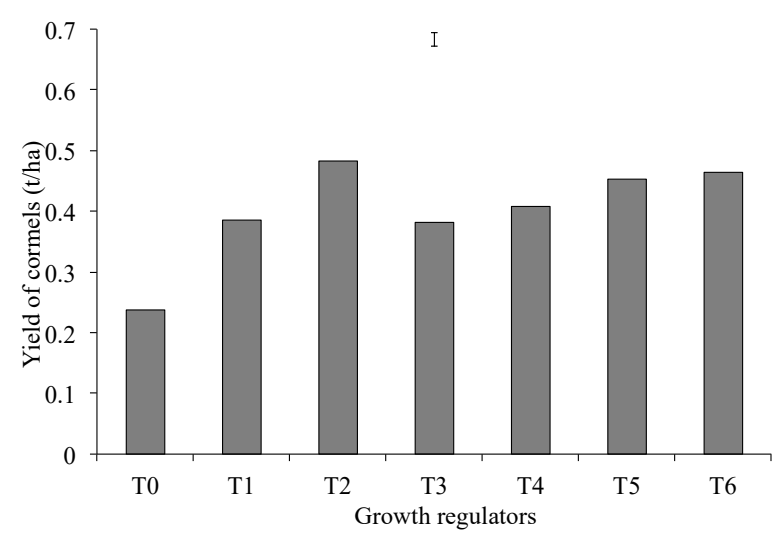

Figure 4. Effect of PGRs on yield of cormels. The vertical bar represents LSD 5\% level of probability.
The maximum size of corms $(6.37 \mathrm{~cm})$ was recorded in GA 3 @ 500 ppm ( $\left.\mathrm{T}_{2}\right)$ closely followed by GA 3 @ 750 ppm $\left(\mathrm{T}_{3}\right)(6.05 \mathrm{~cm})$, respectively, while the minimum size of corms $(3.92 \mathrm{~cm})$ was obtained from control $\left(\mathrm{T}_{0}\right)$. The increase in weight, size and volume of the corms with the application of $\mathrm{GA}_{3}$ can be attributed to increase in number of leaves per plant which increased the photosynthetic assimilates. These assimilates are transported to the resulting daughter corms, thereby, increasing their weight, size and volume. Similar findings have also been reported by Kumar et al. (2002) and Suresh Kumar et al. (2008) in gladiolus. The yield attributes related to corms and cormels are significantly increased by the application of growth regulators in all the concentration when compared to control (Sudhakar and Kumar 2012). It was reported that the maximum corm (13.33 t/ha) and cormel yield $(0.483 \mathrm{t} / \mathrm{ha})$ were recorded with the pre soaking treatment of $\mathrm{GA}_{3} @ 500$ ppm $\left(\mathrm{T}_{2}\right)$, respectively, while the minimum corm (3.48 $\mathrm{t} / \mathrm{ha})$ and cormel yield $(0.238$ $\mathrm{t} / \mathrm{ha}$ ) were observed in control $\left(\mathrm{T}_{0}\right)$ (Figure $3 \& 4$ ). These results are in agreement with the findings of Rana et al. (2005).

Combined effects of corm size and plant growth regulators: The combined effect of corm size and PGRs had significant influence on all the corm and cormel producing parameters under study viz. number of corms and cormels per plant, weight of single corm, weight of corms and cormels per plant, corm size, and yield of corms and cormels per hectare (Table 2). It was observed that the maximum number of corms (2.73) and cormels per plant (17.00) was recorded for interaction effects of $4.1-5 \mathrm{~cm}$ sized corms pre soaked with $\mathrm{GA}_{3} @ 500$ ppm $\left(\mathrm{C}_{2} \mathrm{~T}_{2}\right)$, respectively, whereas the lowest number of corms per plant (1.30) was recorded in 3-4 cm sized corms with control treatment $\left(\mathrm{C}_{1} \mathrm{~T}_{0}\right)$. Treatment combinations of 4.1-5 cm sized corms and $\mathrm{GA}_{3} @ 500$ ppm $\left(\mathrm{C}_{2} \mathrm{~T}_{2}\right)$, closely followed by $4.1-5 \mathrm{~cm}$ sized corms and $\mathrm{GA}_{3} @ 750$ ppm $\left(\mathrm{C}_{2} \mathrm{~T}_{3}\right)$ gave the maximum weight of single corms $60.90 \mathrm{~g}$ and $58.67 \mathrm{~g}$, respectively. On the contrary, the minimum weight of single corm $(30.20 \mathrm{~g})$ was recorded in the treatment 
combination of $3-4 \mathrm{~cm}$ sized corms with control $\left(\mathrm{C}_{1} \mathrm{~T}_{0}\right)$. The maximum weight of corms $(152.17 \mathrm{~g})$ and cormels per plant $(5.50 \mathrm{~g})$ was recorded for the treatment combination of $4.1-5 \mathrm{~cm}$ sized corm and $\mathrm{GA}_{3}$ (a) $500 \mathrm{ppm}\left(\mathrm{C}_{2} \mathrm{~T}_{2}\right)$, while the minimum weight of corms $(38.00 \mathrm{~g})$ and cormels per plant $(2.60 \mathrm{~g})$ was found from the treatment combination of 3-4 $\mathrm{cm}$ sized corm with control $\left(\mathrm{C}_{1} \mathrm{~T}_{0}\right)$. Results revealed that the maximum size or diameter of the corms $(6.63 \mathrm{~cm})$ was recorded with the interaction effects of 4.1-5 cm sized corms and $\mathrm{GA}_{3} @ 500$ ppm $\left(\mathrm{C}_{2} \mathrm{~T}_{2}\right)$, followed by 6.30 $\mathrm{cm}$ in 4.1-5 cm sized corms and $\mathrm{GA}_{3} @ 750 \mathrm{ppm}$ $\left(\mathrm{C}_{2} \mathrm{~T}_{3}\right)$, whereas the minimum corm size $(3.60 \mathrm{~cm})$ was obtained from the interaction effects of 3-4 $\mathrm{cm}$ sized corms with control $\left(\mathrm{C}_{1} \mathrm{~T}_{0}\right)$.

Table 2. Combined effects of corm size and PGRs on corm and cormel production of gladiolus

\begin{tabular}{|c|c|c|c|c|c|c|c|c|}
\hline Treatments & $\begin{array}{c}\text { No. of } \\
\text { corms/ } \\
\text { plant }\end{array}$ & $\begin{array}{c}\text { No. of } \\
\text { cormels/p } \\
\text { lant }\end{array}$ & $\begin{array}{c}\text { Weight of } \\
\text { single } \\
\text { corm }(\mathrm{g})\end{array}$ & $\begin{array}{l}\text { Weight of } \\
\text { corms/ } \\
\text { plant (g) }\end{array}$ & $\begin{array}{c}\text { Weight of } \\
\text { cormels/p } \\
\text { lant }(\mathrm{g})\end{array}$ & $\begin{array}{c}\text { Corm } \\
\text { size }(\mathrm{cm})\end{array}$ & $\begin{array}{l}\text { Yield of } \\
\text { corms } \\
(\mathrm{t} / \mathrm{ha})\end{array}$ & $\begin{array}{c}\text { Yield of } \\
\text { cormels } \\
(\mathrm{t} / \mathrm{ha})\end{array}$ \\
\hline $\mathrm{C}_{1} \mathrm{~T}_{0}$ & 1.30 & 8.10 & 30.20 & 38.00 & 2.60 & 3.60 & 3.42 & 0.233 \\
\hline $\mathrm{C}_{1} \mathrm{~T}_{1}$ & 1.67 & 13.63 & 52.47 & 92.13 & 4.20 & 5.20 & 8.29 & 0.380 \\
\hline $\mathrm{C}_{1} \mathrm{~T}_{2}$ & 2.50 & 16.00 & 58.47 & 144.23 & 5.20 & 6.10 & 12.98 & 0.470 \\
\hline $\mathrm{C}_{1} \mathrm{~T}_{3}$ & 2.20 & 12.50 & 56.53 & 112.70 & 4.17 & 5.80 & 10.14 & 0.377 \\
\hline $\mathrm{C}_{1} \mathrm{~T}_{4}$ & 1.97 & 11.87 & 46.97 & 89.37 & 4.47 & 5.00 & 8.04 & 0.403 \\
\hline $\mathrm{C}_{1} \mathrm{~T}_{5}$ & 2.27 & 12.43 & 45.53 & 109.53 & 4.87 & 4.70 & 9.85 & 0.440 \\
\hline $\mathrm{C}_{1} \mathrm{~T}_{6}$ & 2.50 & 13.77 & 44.00 & 102.10 & 5.00 & 4.93 & 9.18 & 0.450 \\
\hline $\mathrm{C}_{2} \mathrm{~T}_{0}$ & 1.43 & 9.33 & 32.10 & 39.40 & 2.70 & 4.23 & 3.55 & 0.243 \\
\hline $\mathrm{C}_{2} \mathrm{~T}_{1}$ & 2.03 & 13.93 & 54.03 & 99.60 & 4.33 & 5.83 & 8.96 & 0.390 \\
\hline $\mathrm{C}_{2} \mathrm{~T}_{2}$ & 2.73 & 17.00 & 60.90 & 152.17 & 5.50 & 6.63 & 13.69 & 0.497 \\
\hline $\mathrm{C}_{2} \mathrm{~T}_{3}$ & 2.47 & 13.37 & 58.67 & 115.47 & 4.30 & 6.30 & 10.39 & 0.387 \\
\hline $\mathrm{C}_{2} \mathrm{~T}_{4}$ & 2.13 & 12.57 & 48.13 & 92.83 & 4.60 & 5.33 & 8.35 & 0.413 \\
\hline $\mathrm{C}_{2} \mathrm{~T}_{5}$ & 2.63 & 13.23 & 49.63 & 113.10 & 5.13 & 5.03 & 10.17 & 0.463 \\
\hline $\mathrm{C}_{2} \mathrm{~T}_{6}$ & 2.70 & 13.60 & 45.17 & 108.63 & 5.33 & 4.87 & 9.77 & 0.480 \\
\hline $\mathrm{LSD}_{0.05}$ & 0.09 & 0.39 & 0.68 & 1.09 & 0.13 & 0.14 & 0.092 & 0.012 \\
\hline $\begin{array}{l}\text { Level of } \\
\text { significance }\end{array}$ & $*$ & $*$ & $*$ & $*$ & * & * & $*$ & $*$ \\
\hline
\end{tabular}

$\mathrm{C}_{1}=3-4 \mathrm{~cm}, \mathrm{C}_{2}=4.1-5 \mathrm{~cm}, \mathrm{~T}_{0}=$ Control, $\mathrm{T}_{1}=\mathrm{GA}_{3} @ 250 \mathrm{ppm}, \mathrm{T}_{2}=\mathrm{GA}_{3} @ 500$ ppm, $\mathrm{T}_{3}=\mathrm{GA}_{3} @ 750$ ppm, $\mathrm{T}_{4}=$ NAA@ 100 ppm, T $5=$ NAA@ 200 ppm, T $6=$ NAA@ @ 300 ppm.

Increase in corm diameter with 4.1-5 cm sized corm and $\mathrm{GA}_{3}$ treatment might be due to the reservation of food materials and growth regulators effect on cell elongation. Experimental results revealed that the maximum corm (13.69 t/ha) and cormel yield (0.497 $\mathrm{t} / \mathrm{ha}$ ) was obtained from the combined treatment of 4.1$5 \mathrm{~cm}$ sized corms and $\mathrm{GA}_{3} @ 500$ ppm $\left(\mathrm{C}_{2} \mathrm{~T}_{2}\right)$, respectively, while the minimum corm (3.42 t/ha) and 
cormel yield $(0.233 \mathrm{t} / \mathrm{ha})$ was found in $\mathrm{C}_{1} \mathrm{~T}_{0}$. These might be due to the large size of the corms and influence of higher concentration of $\mathrm{GA}_{3}$ which enhanced the growth rate of plant parts, which consequently increases the photosynthetic and metabolic activities causing more transportation and utilization of photosynthetic products like corms and cormels (Chopde et al. 2012; Patel et al. 2010).

\section{Conclusion}

On the basis of the present study, it can be concluded that pre soaking treatment of 4.1-5 cm sized corms with $\mathrm{GA}_{3} @ 500$ ppm followed by 4.1-5 cm sized corms with $\mathrm{GA}_{3} @ 750$ ppm was found to be best for corm and cormel production of gladiolus.

\section{References}

Baskaran V, Misra RL (2007). Effect of plant growth regulators on growth and flowering of gladiolus. Indian Journal of Horticulture, 64: 479-482.

Baskaran V, Misra RL, Abirami K (2009). Effect of plant growth regulators on corm production in gladiolus. Journal of Horticultural Science, 4(1):

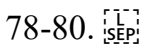

Bhat ZA, Paul TM, Mir MM (2009). Effect of corm size and planting geometry on growth, flowering and corm production in gladiolus cv. white prosperity. Journal of Ornamental Horticulture, 12(1): $35-38$.

Bhattacharjee SK (1983). Response of Lilium tigrinum Ker- Gawl (tiger lily) to soil drench application of growth regulating chemicals. Progressive Horticulture, 15: 204-209.

Chopde N, Gonge VS, Dalal SR (2012). Growth, flowering and corm production of gladiolus as influenced by foliar application of growth regulators. Plant Archives 12(1): 41-46.

Dua IS, Sehgal OP, Chark KS (1984). Gibberellic acid induced earliness and increased production in gladiolus. Gartenbauwissenschaft, 49: 91-94.

El-Meligy MM (1982). Effect of gibberellin and radiation on corm formation and anthocyanin content in gladiolus. Agricultural Research Review, 60: 265-280 :

Hong YP, Goo DH, Huk KY (1989). Studies on corm formation in Gladiolus grandavensis: the effects of planting date of cormels on corm production, dormancy and flowering of the corm in the next generation. Research Report Rural Development Administration Horticulture, 31:54-59.

Kalasareddi P, Reddy B, Patli S, Ryagi YY, Gangadharappa P (1998). Effect of corm size on growth and spike yield of gladiolus cv. Snow White. Karnataka Journal of Agricultural Sciences, 4:1133-1135.

Khan FN, Rahman MM., Hossain MM, Hossain T (2011). Effect of benzyladenine and gibberellic acid on dormancy breaking and growth of gladiolus cormels. Thailand Journal of Agricultural Science, 44:165-174.

Kumar R, Dubey RK, Misra RL (2002). Effect of $\mathrm{GA}_{3}$ on growth, flowering and corm production of gladiolus, In: Floriculture Research Trend in India, Misra R.L. and Sanyat Misra, (Eds.). ISOH, New Delhi, India, 2002, 110-113.

Mahesh KS (1992). Effect of growth regulators on gladiolus var. Snow Princes. M.Sc. thesis, IARI, New Delhi.

Mahesh KS, Misra RL (1993). Effect of growth regulators on gladiolus. Journal of Ornamental Horticulture, 1(2): 12-15.

Mayak S, Halevy AH (1980). Flower senescence plants Thimanna, V. CRC press, Boca Raton, 132.

McKay ME, Byth DE, Tommerup J (1981). The effect of corm size and division of the mother corm in gladioli. Australian Journal of Experimental Agriculture and Animal Husbandry, 21:343-348.

Memon NUN, Wahocho NA, Miano TF, Leghari MH (2016). Propagation of gladiolus corms and cormels: A review. African Journal of Biotechnology, 15(32): 1699-1710.

Mitra R (1992). Gladiolus. Fuler Bagan (31 part). Indian Book Agency, 11/27, Temer Lane, Calcutta, pp.158-168. 


\section{Corm and cormel production of gladiolus}

Mollah MS, Islam S, Rafiuddin, Choudhury SS, Saha SR (1995). Effect of cormel size and spacing on growth and yield of flower and corm of gladiolus. Bangladesh Horticulture, 23: 67-71.

Mukhopadhyay TK, Yadav LP (1984). Effect of corm size and spacing on growth, flowering and production of gladiolus. Haryana Journal Horticultural Science, 13:95-99.

Patel J, Patel HC, Chavda JC, Saiyad MY (2010). Effect of plant growth regulators on flowering and yield of gladiolus (Grandiflorus L.) cv. American beauty. The Asian Journal of Horticulture 5(2): 483-485.

Rana P, Kumar J, Kumar M (2005). Response of $\mathrm{GA}_{3}$, plant spacing and planting depth on growth, flowering and corm production in gladiolus. Journal of Ornamental Horticulture, 8(1): 41-44.

Roy S, Fatmi U, Kumar S, Sudhir Kumar Mishra, Singh R (2017). Effect of pre plant soaking of corms in growth regulators on sprouting, vegetative growth and corm formation in gladiolus (Gladiolus grandiflorus L.). Journal of Pharmacognosy and Phytochemistry, 6(5): 11351138.

Singh KP (1996). Studies on size of cormel and levels of nitrogen on corm multiplication in gladiolus. Advanced Plant Science 9(2): 241-243.

Singh SP (1992). Gladiolus Cultivation. Associated Pub Com New Dehli pp. 1-38.
Sinha P, Roy SK (2002). Plant regeneration through In vitro cormel formation from callus culture of Gladiolus primulinus Baker. Plant Tissue Culture, 12:139-145.

Sinha P, Roy SK (2002). Plant regeneration through In vitro cormel formation from callus culture of Gladiolus primul inus Baker. Plant Tissue Culture, 12:139-145.

Sudhakar M, Kumar SR (2012). Effect of growth regulators on growth, flowering and corm production of gladiolus (Gladiolus grandiflorus 1.) cv. white friendship. Indian Journal of Plant Science, 1(2-3): 133-136.

Suresh KP, Bhagawat R, Rajiv K, Ronya T (2008). Effect of plant growth regulators on vegetative growth, flowering and corm production of gladiolus in Arunachal Pradesh. Journal of Ornamental Horticulture, 11(4): 265-270.

Syamal MM, Rajput CBS, Singh SP (1987). Effect of corm size, planting distance and depth of planting on the growth and flowering of gladiolus. Research Development Report 4:10-12.

UNDP, FAO (1988). Land Resources Appraised of Bangladesh for Agricultural Development. AgroEcological Regions of Bangladesh, Report 2, Food and Agriculture Organisation of the United Nations (FAO), 63: 105-229. 